\title{
O "Perigo Vermelho" em Americana (SP): a trajetória de Romeu Sturari, por uma história de lutas dos trabalhadores de Vila Operária de Carioba (1947-1967)
}

\section{The "Red Danger" in Americana (SP): the trajectory of Romeu Sturari, for a history of struggles of the workers of Vila Operária de Carioba (1947-1967)}

\section{Luís Henrique Carboni Junior*}

Resumo: Este artigo investiga a trajetória de Romeu Sturari, tecelão da Fábrica de Tecidos Carioba e morador em Vila Operária de Carioba, como meio de acesso ao conhecimento histórico sobre a organização do movimento operário em Vila Operária e em Americana (SP). Através de sua trajetória, pretende-se aferir: a influência do Partido Comunista Brasileiro (PCB) na cidade, a ação do sindicato têxtil, os modos de organização e de luta adotados pelos trabalhadores nas diferentes conjunturas, os efeitos do golpe militar de 1964 no município e, finalmente, a situação experienciada pelos trabalhadores durante a Grande Greve de Carioba em meados da década de 1960.

Palavras-chave: Movimento operário (Americana); Vila Operária da Fábrica de Tecidos Carioba; Romeu Sturari (1918-1978).

Abstract: This article investigates the trajectory of Romeu Sturari, weaver in Fabrics Factory of Carioba and residente in Worker Village of Carioba, as a means of accessing historical knowledge about the organization of the Labor Movement in the Worker Village and Americana (SP). With this trajectory we intend to measure: the influence of the Brazilian Communist Party (PCB) in the city, the action of Textile Syndicate, the ways of organization and struggle adopted by workers in diferents circunstances, the affects of the Military Coup of 1964 in the

* Mestrando em História Social do Trabalho pela Universidade Estadual de Campinas (Unicamp). Bolsista do Conselho Nacional de Desenvolvimento Científico e Tecnológico (CNPq). E-mail: luiscarboni.2@gmail.com. ORCID: https://orcid.org/0000-0002-2373-5312. 
municipality and, finally, the situation experienced by workers during the Carioba's Great Strike in the mid-1960s.

Keywords: Labor Movement (Americana); Worker Village of Fabrics Factory of Carioba; Romeu Sturari (1918-1978).

\section{Introdução}

D ETIDO quando iria visitar sua família em Americana, no dia 25 de fevereiro de 1965, encontrava-se na Delegacia de Ordem Política e Social de São Paulo (DOPS), o até então foragido, Romeu Sturari. Tecelão de instrução primária, descendente de italianos, 1,75 m, contando 46 anos, casado com Genny Polido Sturari, era pai de 6 filhos e avô de 2 netos, mas que "desde jovem atuava como agitador". ${ }^{1}$ Sua última prisão, decretada dois meses após o golpe militar, tinha como base a Lei de Segurança Nacional $n^{0} 1.802 / 53$, seu crime consistia na "implantação do comunismo peleguista nos meios sindicais, forjando greves, forjando a luta de classes, e incutindo no trabalhador americanense as ideias esquerdistas". Lembrava-se de ter sido detido por "quatro ou cinco vezes" pela polícia política e social, sendo identificado pelas autoridades como aquele que "participou e provou todas as greves de Americana", era o "chefia dos comunistas americanenses".

Menos de uma semana após o golpe militar, Sturari fugiu para São Paulo temendo ser preso, pois era "velho conhecido" das autoridades e de toda a população de Americana por atividades comunistas "em praça pública". Quando detido, ocupava o cargo de presidente do Sindicato dos Trabalhadores na Indústria de Fiação e Tecelagem de Americana, desde dezembro de 1958; era juiz vogal dos trabalhadores na Junta de Conciliação e Julgamento da Justiça do Trabalho desde 1962; e, por fim, suplente no conselho da Federação dos Trabalhadores nas Indústrias de Fiação e Tecelagem do Estado de São Paulo.

Mas sua trajetória junto aos trabalhadores americanenses nos arquivos do DOPS ${ }^{2}$ remonta a meados da década de 1940, podendo ser descrita literariamente como uma epopeia. ${ }^{3}$ Seu nome é citado uma centena de vezes na Pasta Americana, de 1947 a 1965. Há, também, menções de suas atividades no Dossiê Comunismo - PCB, bem como na imprensa, seja ela local ou operária. Sendo assim, são essas as principais fontes documentais ${ }^{4}$ que permitem a investigação de sua trajetória e a escrita do artigo. ${ }^{5}$

1 Todas as citações diretas sem referência são retiradas dos documentos produzidos pelas autoridades policiais da Delegacia de Ordem Política e Social (São Paulo) em conjunto com a Delegacia de Americana.

2 Pasta Americana. Arquivo Público do Estado de São Paulo, Fundos: DEOPS/SP.

3 No sentido de que Romeu Sturari é um indivíduo capaz de representar uma coletividade em diferentes conjunturas históricas.

4 Um levantamento prévio dessa documentação foi apresentado em Simpósio Temático do IV Encontro Estadual da ANPUH/Amapá, 2020.

5 Agradecimentos especiais a Vanessa Parazzi, neta de Romeu Sturari, que gentilmente cedeu fotografias e documentos pessoais do acervo particular da família. 
O artigo está dividido em sete principais seções, conforme critérios temáticos e temporais, mesclando momentos importantes da política nacional e da trajetória de vida do tecelão junto aos companheiros de trabalho: a primeira parte pretende esclarecer aspectos gerais da vila operária e expor a metodologia e objetivos de se investigar Romeu Sturari como meio de compreender tanto o regime patronal existente em Carioba quanto as relações dos trabalhadores com a política local e nacional. Posteriormente, é investigada a ação de Sturari em Carioba, tendo como base a recente legalização do PCB, as possibilidades eleitorais e os meios de propaganda e luta adotados pelo militante. O terceiro tópico aborda o período de clandestinidade de Sturari, condenado, pela primeira vez, na Lei de Segurança Nacional de 1953. O quarto tópico trata do período pós-anistia, quando Sturari retoma sua militância, priorizando o viés sindical. A quinta sessão investiga os impactos do golpe militar de 1964 e da caça aos comunistas para o movimento operário e para política local, processo que acarretou uma segunda condenação na Lei de Segurança Nacional. O penúltimo tópico aborda a conjuntura da Grande Greve de Carioba, privilegiando reconhecer os motivos do embate entre as classes, bem como os recursos de negociação adotados pelos operários. Por fim, a conclusão pretende retomar as constatações que a trajetória de Romeu Sturari nos permitiu aferir sobre as movimentações trabalhistas em Vila Operária de Carioba.

\section{Romeu Sturari e Vila Operária de Carioba: metodologia e objetivos}

NASCIDO NO DIA 12 de novembro de 1918, em Americana, Romeu Sturari iniciou sua vida operária em 1932, quando mudou-se com sua família para a Vila Operária de Carioba, propriedade da Fábrica de Tecidos Carioba. Lá, aos 14 anos, adquiriu saberes que o permitiram ascender ao cargo de tecelão. Sua trajetória profissional era semelhante à de muitos outros trabalhadores da tecelagem, "vindos de fazendas e sítios e que aqui [...] aprenderam a se tornar tecelões".

Localizada entre as margens do rio Piracicaba e do ribeirão Quilombo, no interior de São Paulo, a Fábrica de Tecidos Carioba foi um dos primeiros grandes empreendimentos industriais do ramo têxtil no Brasil. Fundada em 1875 por iniciativa dos irmãos Antônio e Augusto Souza e Queiroz, em sociedade com William Pultney Talston, a tecelagem passou por diversas administrações. Em 1882, a fábrica foi vendida para os irmãos ingleses Clement e Jorge Wilmont, os quais iniciaram a construção da Vila Operária de Carioba. Entretanto, de 1886 a 1901, a fábrica não operou até ser arrematada pela Rawlinson Müller e Companhia, principais responsáveis pela expansão e consolidação da vila operária. Em 1918, a vila concentrava mais de 220 casas operárias, sendo habitada, em sua maioria, por imigrantes italianos ou descendentes. Vale ressaltar que o recorte temporal abarcado pela pesquisa se concentra na administração do Grupo J. J. Abdalla, que se estendeu de 1944 até 1976. 
Nas primeiras décadas do século XX, Carioba consolidou-se como independente polo urbano-industrial, concentrando a vida operária de Americana, reconhecida como "verdadeira cidadezinha". A infraestrutura era ampla: havia a Sociedade de Mútuo Socorro; o Clube Recreativo e Sportivo de Carioba, que além do time de futebol contava com biblioteca, eventos de jogos e dança, banda e desfiles de carnaval; bem como o Clube de Regatas e Natação Carioba. No âmbito educacional e cultural havia o Grupo Escolar Carioba e o Cine Carioba. Assim, com a expansão fabril e oferta de empregos, Carioba tornou-se receptora de trabalhadores, ocupando, por mais de meio século, o posto de maior indústria da cidade, influenciando o curso e o ritmo do desenvolvimento de Americana.

$\mathrm{Na}$ década de 1940, a cidade viveu um processo de multiplicação de centenas de pequenas fabriquetas têxteis, as chamadas facções, destinadas à produção de rayon, setor que, apesar das sucessivas crises, era a manufatura dominada pelos tecelões, dada a implementação pela Fábrica de Tecidos Carioba. Outro modo de influência deu-se nos cargos dos poderes Executivo e Legislativo da Câmara Municipal; todas as diferentes administrações da Carioba ocuparam cargos públicos.

A popularidade política de seus administradores tem explicações na relação de trabalho estabelecida em Carioba, definida como paternalismo industrial, uma vez que os administradores residiam próximos à vila e transitavam pelos mesmos locais que os trabalhadores, permitindo interação e convívio entre as classes, o que contribuía para a construção de uma falsa concepção de harmonia entre patrão e empregado. Essa acessibilidade ao patrão fazia com que muitos trabalhadores os vissem como "compadres". Outro fator importante era o "peculiar regime de política social [...] Geopoliticamente formando quase uma cidade com vida independente, têm os operários casa, luz e água fornecidos pelo patrão".

Havia, desse modo, uma concepção entre os trabalhadores de dívida de lealdade com os empregadores, provedores do bem-estar e dos meios de subsistência. A ampla variedade de atividades recreativas, a modernização, o sentimento de pertencimento e a falsa sensação de igualdade classista possibilitaram aos trabalhadores urdirem uma memória idílica sobre Vila Carioba. O sentimento de orgulho em se denominar cariobense ${ }^{6}$ revela, por meio de memorialistas e relatos orais, o imaginário de um lugar alheio aos conflitos de classe. Contudo, a ação de Romeu Sturari junto aos trabalhadores, presente na documentação policial, revela a luta classista, com seus influxos e refluxos, de reivindicações dos trabalhadores, entre 1947 e 1967, empregando diferentes estratégias político-organizacionais e modos de luta por seus direitos, sendo Carioba o principal foco de organização operária. Como veremos, o meio sindical, mas não somente, consolidou-se como importante via para o questionamento do comando patronal e ruptura com a suposta dívida de lealdade. ${ }^{7}$

6 Os próprios americanenses se diferenciam, destacando seu local de origem, denominando-se cariobense aquele que nasceu ou por muito tempo viveu em Vila Operária de Carioba.

7 NEGRO, Antonio Luigi; SILVA, Fernando Teixeira da. Trabalhadores, sindicatos e política (1945-1964). In: FERREIRA, Jorge; DELGADO, Lucilia de Almeira (org.). O Brasil Republicano: o tempo da experiência democrática. Rio de Janeiro: Civilização Brasileira, 2003. p. 89. 
Foi após a aquisição da Fábrica de Tecidos Carioba pelo Grupo J. J. Abdalla que as greves e a perseguição a Sturari se tornaram constantes. A trajetória do comunista e sindicalista juntamente com a organização dos trabalhadores de Vila Carioba e de Americana aparecem entrelaçadas nos arquivos da repressão. Investigar o tecelão que dá título ao artigo não se justifica como um fim em si mesmo, mas pretende-se adotar o método onomástico como bússola para guiar a pesquisa nos arquivos, possibilitando a reunião de documentos e eventos aparentemente desconectados. ${ }^{8}$ Não obstante, optar por circunscrever a investigação a um determinado local (Vila Carioba), a um determinado indivíduo (Romeu Sturari) e durante um curto espaço temporal (1947-1967) são elementos que possibilitam sobrepor a série documental reunida e encontrar o mesmo indivíduo em diferentes contextos sociais, agindo a partir de diferentes estratégias. ${ }^{9}$ Escolher Romeu Sturari justifica-se, ainda, na suposição de que seja capaz de representar vários outros trabalhadores americanenses derrotados em seus projetos políticos e sociais. ${ }^{10}$

Ao resgatar o papel da ação individual na construção dos processos históricos, o historiador E. P. Thompson tinha como objetivo recuperar tradições e projetos contestatórios derrotados, estabelecendo uma relação dialética entre a ação individual e as implicações sociais decorrentes, de acolhimento ou repressão. ${ }^{11}$ Enquanto Eric Hobsbawm, por sua vez, utilizava seu agente histórico como microcosmos para a compreensão de problemas mais amplos da historiografia do movimento operário e do tempo em que o indivíduo viveu. ${ }^{12}$

Nas palavras de Sabina Loriga, investigar movimentos individuais nos permite:

[...] romper as homogeneidades aparentes (por exemplo, a instituição, a comunidade ou o grupo social) e revelar os conflitos que presidiram a formação e a edificação das práticas culturais: penso na inércia e na ineficácia normativas, mas também nas incoerências que existem entre as diferentes normas, e na maneira pela qual os indivíduos, 'façam' eles ou não a história, moldam e modificam as relações de poder. ${ }^{13}$

Diante de tais premissas metodológicas, as ações humanas passam a ter peso decisivo na investigação de grupos bem delimitados no tempo e no espaço, devendo-se recompor as redes de interação entre os indivíduos e o contexto que os cerca para compreender as escolhas de estratégias de ação. Os modos de luta de que lançam mão não possuem dinâmica autônoma, pois, além do jogo relacional social, sofrem interferência das estruturas normativas. Trata-se de analisar como os trabalhadores lutavam dentro dos interstícios de liberdade existentes nas incoerências das normas. ${ }^{14}$

8 GINZBURG, Carlo; PONI, Carlo. O nome e o como: troca desigual e mercado historiográfico. In: GINZBURG, Carlo; CASTELNUOVO, Enrico; PONI, Carlo. A micro-história e outros ensaios. Lisboa: Difel, 1989. p. 171.

9 Ibidem, p. 174-175.

10 SCHMIDT, Benito Bisso. História e biografia. In: CARDOSO, Ciro; VAINFAS, Ronaldo (org.). Novos domínios da história. Rio de Janeiro: Elsevier, 2012. p. 195.

11 Ibidem, p. 193-194.

12 SCHMIDT, Benito Bisso. Trajetórias e vivências: as biografias na historiografia do movimento operário brasileiro. Projeto História, São Paulo, v. 16, 1998, p. 238.

13 LORIGA, Sabina. A biografia como problema. In: REVEL, Jacques (org). Jogos de escalas: a experiência da microanálise. Rio de Janeiro: Editora FGV, 1998. p. 249.

14 LEVI Giovanni. Un problema de escala. Relaciones: Estudios de historia y sociedade, Mexico, v. 24, n. 95, ver. 2003, p. 282-284. 
Desse modo, ao darmos a devida atenção à Vila Carioba, temos maiores chances de desvendar os sistemas e os modos de exercício de poder entre as classes diante de um quadro empírico, privilegiando a trajetória como via de acesso para recomposição das tensões existentes entre o individual e o social em Carioba. ${ }^{15} \mathrm{Em}$ suma, pretende-se investigar a agência de Romeu Sturari como prisma de observação para lançar novas perspectivas sobre a formação da classe operária de Americana.

Portanto, o objetivo do artigo é evidenciar a existência, em Vila Carioba, de disputas classistas e projetos políticos dos trabalhadores, que sucumbiram durante o processo histórico, propondo um revisionismo, na memória e na historiografia sobre o município, sobre a agência dos trabalhadores. Para tanto, iremos recuperar agentes sociais e eventos históricos até então excluídos e silenciados. Além disso, investigar essa conjuntura nos permite aferir sobre a atuação do Partido Comunista Brasileiro (PCB) em Americana, a repressão política e ideológica durante o período de redemocratização, os efeitos do golpe militar na cidade e, por fim, analisar brevemente a "Grande Greve" de Carioba.

\section{“Perigo Vermelho": o PCB em Americana (1947-1953)}

O PERÍODO de redemocratização foi marcado pela industrialização rápida e migração de trabalhadores do campo para a indústria. Ao passo que, para os governantes e industriais, a figura do "trabalhador cidadão" não deveria ser almejada nesse perfil do migrante, pois era tido como servo do atraso, de ação histórica inepta, incapaz de inventar suas tradições sociais, culturais ou políticas de forma independente. Assim, o jovem operariado urbano, imaturo e sem tradição trabalhista, deveria ser assistido e vigiado pelo poder público, para preservar seu eminente caráter dócil, cordial e ordeiro. Portanto, o trabalhador tinha de ser protegido pelo Estado, via Ministério do Trabalho, que estaria incumbido de o resguardar tanto da luta classista quanto da exploração capitalista. ${ }^{16}$

Todavia, os trabalhadores de Americana, em especial Romeu Sturari, não se comportaram de modo inerte, tomando iniciativas na organização política e reivindicativa dos direitos da classe trabalhadora. A redemocratização que marcava o fim do sufocamento político "se abria para os trabalhadores com esperança de justiça e liberdade [...] A volta à democracia implicava invenção de direitos, que por sua vez implicava exigência de seu cumprimento, que dependia da organização e participação dos trabalhadores". ${ }^{17}$ É nesse contexto que trabalhadores lançaram empreitadas eleitorais, envolvendo-se com projetos políticos até então ilegais, como o do PCB.

Diante das novas possibilidades, Romeu Sturari concorreu a deputado estadual pelo PCB em janeiro de 1947. A partir de então, o anonimato do tecelão nos arquivos do DOPS

15 SCHMIDT, op. cit., 1998, p. 139-140.

16 NEGRO; SILVA, op. cit., p. 49-50.

17 Ibidem, p. 51. 
terminou, entrando definitivamente na mira das autoridades. Contudo, ser anônimo para as autoridades não significava estar alheio ao movimento dos trabalhadores, pois, conforme o jornal Hoje, quando se candidatou, Sturari era "destacado dirigente sindical [...] tendo obtido expressiva votação", ${ }^{18}$ apesar de não ter sido eleito.

Com a legalização, o PCB buscou consolidar-se como um partido ordeiro, respeitando a via eleitora, todavia, associavam a luta pela liberdade democrática com os direitos da classe trabalhadora. ${ }^{19}$ Entretanto, antes das eleições municipais ocorrerem em novembro, o então presidente Dutra viu-se obrigado a colocar o Brasil na dinâmica da Guerra Fria para manter boas relações internacionais com os Estados Unidos, decretando, novamente, a ilegalidade do PCB e intervenções do Ministério do Trabalho nos sindicatos, sob o pretexto de que essas instituições não deveriam interferir nos movimentos sociais. Com a crescente pressão, o governador de São Paulo Ademar de Barros aceitou a caça aos comunistas, tornando-se traidor aos olhos dos trabalhadores que outrora lhe apoiaram e o elegeram. ${ }^{20}$

Em decorrência da ilegalidade, sedes do PCB foram invadidas e fechadas pela polícia, como ocorrido com o Comitê Municipal do Partido Comunista de Americana, do qual Sturari declarou-se secretário político. Durante a ação policial, foram apreendidas 34 fichas de filiação de americanenses, incluindo nove mulheres e oito residentes de Vila Carioba.

Imagem I: Ficha de filiação ao PCB de Rosa Sturari, moradora de Vila Carioba

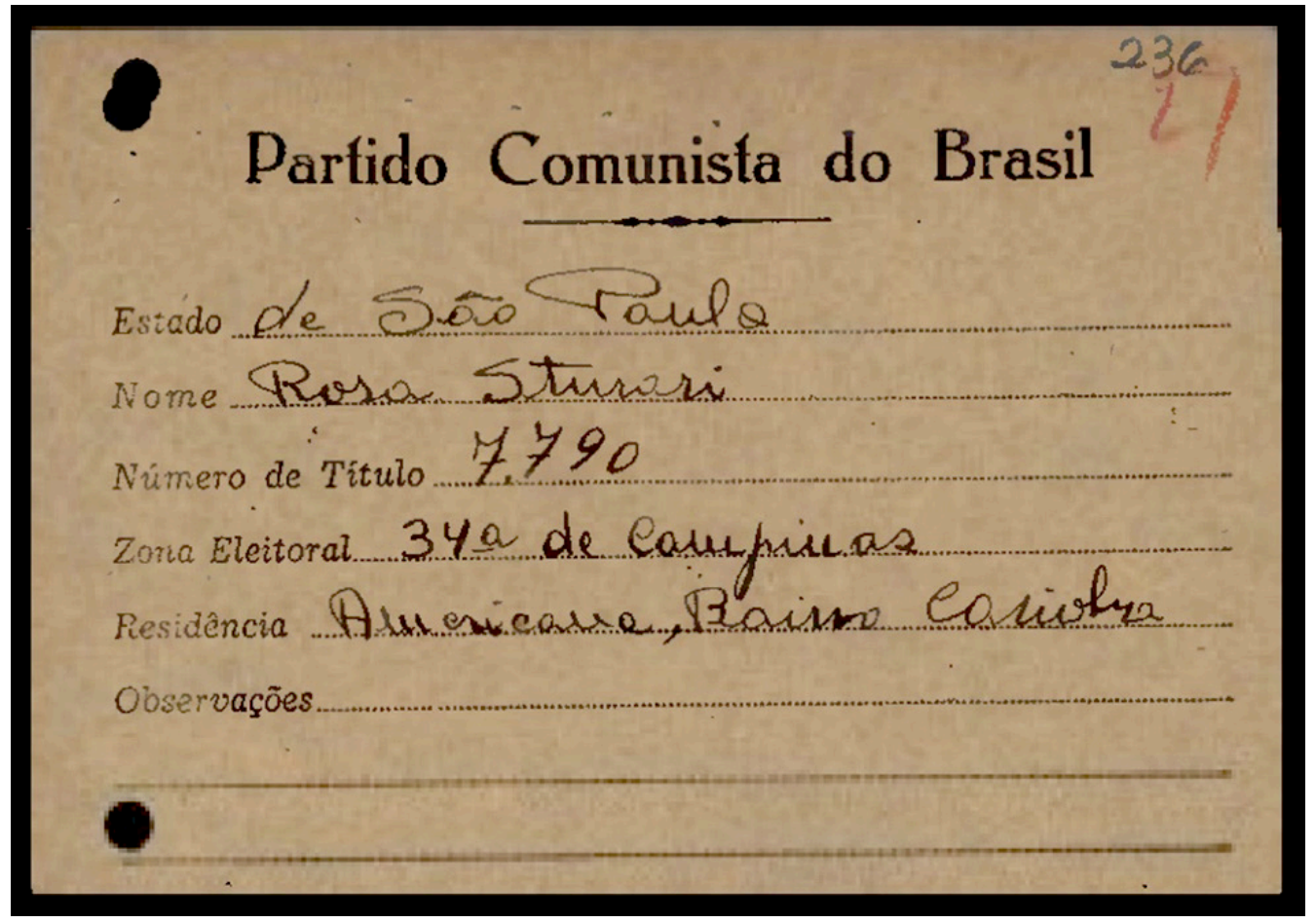

Fonte: Dossiê Comunismo - PCB, Delegacia de Ordem Política e Social.

18 Hoje, São Paulo, 19 out. 1947.

19 NEGRO; SILVA, op. cit., p. 56.

20 Ibidem, p. 59. 
Órfãos de partido, muitos dos então filiados ao PCB migraram para o Partido Social Trabalhista (PST) como meio de viabilizar as candidaturas municipais. ${ }^{21}$ Graças ao acordo político entre "comunistas e democratas de Americana", ${ }^{22}$ os comunistas candidatos a vereador foram lançados sob a legenda do PST, sendo recebidos com "caloroso apoio popular". Conforme o DOPS, Sturari, o "candidato de Prestes" em ambas as eleições, tinha como pretensão angariar votos da imagem de "líder dos operários têxteis [...] na luta pelas reivindicações da classe, que the valeu perseguições dos empregadores".

Passadas as eleições, em dezembro de 1947, Sturari foi afastado de sua função de tecelão para responder ao processo administrativo instaurado pelos Abdalla. A justificativa era de que o empregado atuava "contra os interesses da empresa", pois era "elemento agitador e incitador de greve". O processo estendeu-se até 1951, conforme o Jornal do Commercio ${ }^{23}$ e o Correio Paulistano, ${ }^{24}$ visto que ambas as partes tentaram recorrer às decisões promulgadas pelo Tribunal Regional do Trabalho. Por fim, foi demitido, mas recebeu todos os valores que Ihes eram legalmente cabíveis. Segundo as autoridades, dois anos após seu afastamento não exerceu nenhuma outra atividade profissional, dedicando-se somente a "agitar os operários, sendo [...] sustentado com sua família por elementos do PCB".

Outro "candidato de Prestes" nas eleições municipais, sob a legenda do PST, era Álvaro Cecchino, industriário do ramo têxtil que atuava conjuntamente com Sturari. Cecchino era fundador da Cooperativa Industrial de Tecidos de Rayon (CITRA), primeira experiência cooperativa no ramo têxtil; posteriormente, vendeu suas ações e fundou a Distribuidora de Tecidos de Rayon de Americana (DISTRAL). No final dos anos de 1940, Sturari e Cecchino eram os principais comunistas da cidade investigados pelo DOPS. Cecchino era presidente do Comitê Municipal do PCB, classificado como o "cérebro e o mentor do Partido", mas "devido ao cargo que ocupa não aparece em público como executante". Por outro lado, não era capaz de "despertar simpatia na massa operária", pois, como patrão, "dispensava e entrava em constantes choques com seus operários".

Romeu Sturari, que aguardava a "saída dos operários, às 23 horas, para doutriná-los", era o grande temor das autoridades:

auxiliado por outros membros do Partido, está fazendo uma grande e eficiente propaganda, que trará consequências gravíssimas e prejudiciais caso esse indivíduo não seja detido o mais breve possível. Tem muita influência entre o operariado e não perde ocasião de usá-la. Seu palavreado tem o dom de convencer a massa inculta [...] está tentando por todos os meios levar os operários da firma Carioba S/A à greve. É tão audacioso que para conseguir seus fins não hesita em afirmar aos operários que dentro de poucos dias os comunistas tomarão as rédeas do governo brasileiro. Sua demagogia tem influído na mente dos operários e é bem provável que, caso Sturari não seja afastado, dentro de dias as fábricas de Carioba estarão em greve.

21 Ibidem, p. 60

22 Hoje, São Paulo, 19 out. 1947.

23 Jornal do Commercio, Rio de Janeiro, 30 mar. 1950. (Fábrica de Tecidos Carioba recorre às decisões do TRT, pedido negado).

24 Correio Paulistano, São Paulo, 3 dez. 1951. (Romeu Sturari apela contra Fábrica de Tecidos Carioba, pedido negado). 
Em fevereiro de 1948, Sturari foi investigado por coordenar a distribuição de larga tiragem do Manifesto de Janeiro de 1948. A impressão teria sido financiada por Cecchino e o material distribuído em Vila Carioba e outros pontos de Americana, bem como em municípios vizinhos: Santa Bárbara d'Oeste e Piracicaba. Após a cassação do mandato dos parlamentares do $\mathrm{PCB}$, o manifesto demarcava o término da política de união nacional e início da luta contra o governo de traição de Dutra e Barros. Período marcado pelo enfrentamento direto dos membros do partido com as autoridades policiais, igualmente pelo incentivo, conforme orientações do partido, ao abandono do corporativismo e dos sindicatos oficiais. ${ }^{25}$

Entre março e junho, Sturari foi duas vezes apresentado ao DOPS para prestar esclarecimento sobre a "distribuição de boletins nas fábricas de tecelagem". Entretanto, devido à insuficiência de provas "não houve relatório" e foi colocado em liberdade. Mas, o tecelão prosseguia sua militância, escrevendo artigos publicados em diversos jornais comunistas, como A Crítica. ${ }^{26}$ Além disso, recebia e distribuía, na Estação Ferroviária de Americana, materiais como Zé Brasil, Karl Marx, Luís Carlos Prestes e exemplares do Hoje, realizando campanha para angariar fundos para o jornal. Era, também, "encarregado da Campanha de Ajuda à Imprensa Popular. Cuidando exclusivamente dos interesses do Partido".

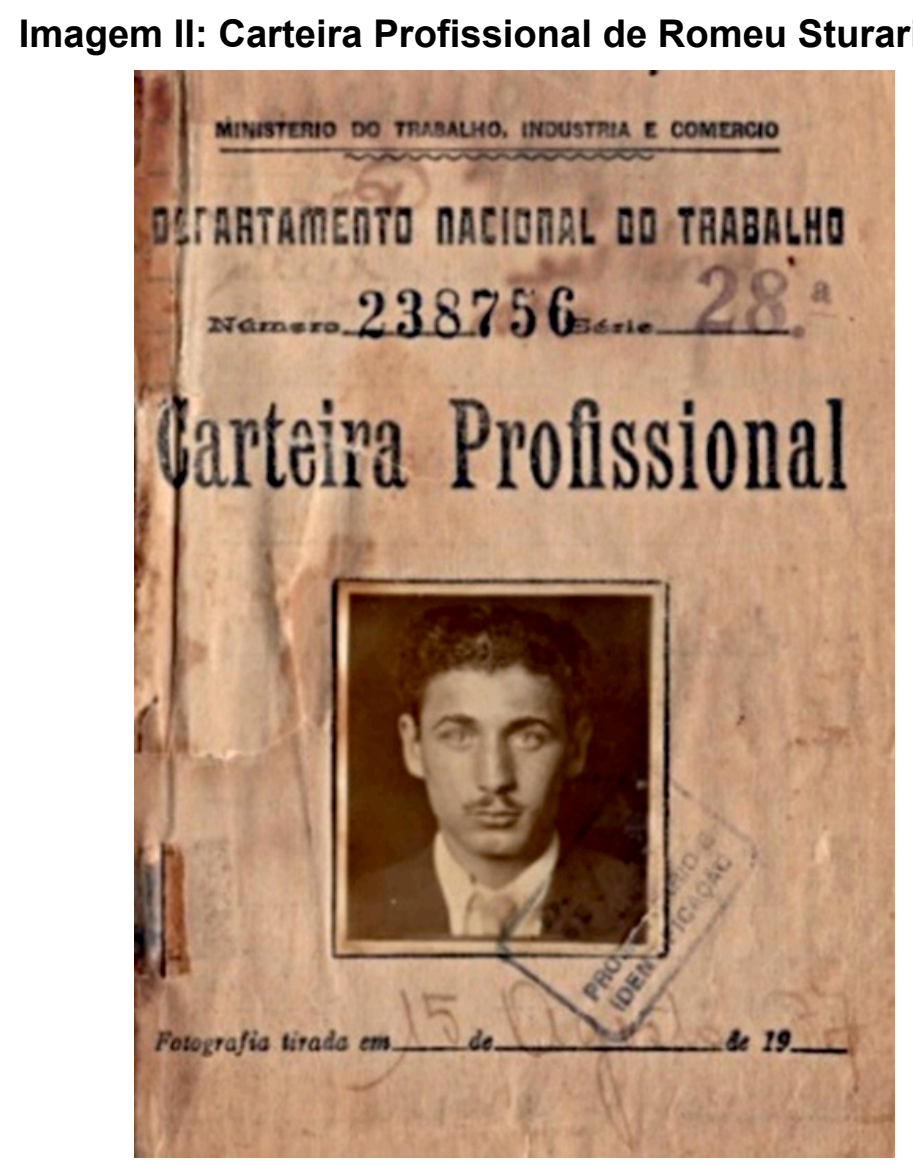

Fonte: Acervo particular da família Sturari.

25 NEGRO; SILVA, op. cit., p. 60.

26 A Crítica, 26 ago. 1948. 
Por estarem articulando greve prevista para final de outubro, as autoridades do DOPS cumpriram um mandado de prisão contra Cecchino e Sturari como meio de silenciar o movimento dos trabalhadores. Cecchino não foi localizado por estar em viagem, enquanto Sturari fugiu dos agentes que tentaram, à meia-noite, capturá-lo em sua residência em Vila Carioba, onde foi encontrado "farto material subversivo". Contudo, nos últimos dias de novembro, Sturari foi apreendido por um praça que o localizou distribuindo jornais ${ }^{27}$ pela cidade, mas, lavrado o ato de apreensão, foi liberado.

Com as novas diretrizes do PCB incentivando a criação de outras instituições, os comunistas americanenses fundaram, no início de 1949, a Comissão Municipal de Estudos e Defesa do Petróleo. Durante a cerimônia de posse, ocorrida no salão de festas do Rio Branco Futebol Clube, houve a formalização escrita de um protesto, encaminhado ao deputado Euzébio da Rocha, contra a Lei de Segurança. Alegavam que a lei consistia em um "castigo para o povo, impedindo-o de exercer o seu direito sagrado, que é defender o petróleo e as demais riquezas de nosso país". ${ }^{28} \mathrm{O}$ manifesto era assinado por Sturari, Cecchino e outros.

As pautas das reuniões da comissão concentravam-se em atacar o capitalismo e o imperialismo norte-americano, criticando o acordo militar estabelecido entre Brasil e Estados Unidos. Apelavam aos operários para que, "em seus locais de trabalho, cooperassem com a Comissão, carreando adesão". Para o DOPS, estava claro que a comissão era "a nova modalidade de atividades dos elementos extremistas, para reerguimento do extinto Partido Comunista".

Nesse período, Americana era uma cidade majoritariamente industrial e urbana, com 190 fábricas,$^{29} \mathrm{em}$ sua maioria do ramo têxtil. A população urbana do município, de aproximadamente 20 mil habitantes, era constituída em quase sua totalidade por operários. A Fábrica de Tecidos Carioba somava dois mil funcionários, sendo um local "isolado" que abrigava "cerca de 700 adeptos do credo vermelho", constituindo "um ótimo ponto para sabotarem a indústria nacional". As benfeitorias e o maquinário estavam avaliados em "mais de 100 milhões de cruzeiros".

Em contrapartida, a Delegacia de Polícia de Americana era uma delegacia de $5^{\text {a }}$ classe, tendo à disposição somente quatro praças. Temendo as manifestações dos trabalhadores, o investigador do DOPS sentia-se "forçado a admitir que esta Delegacia não possui elementos [...] suficientes para uma repressão à altura do que vem acontecendo". Os operários pichavam muros com os dizeres: "Queremos 40\%", "P.C.B.", "Abaixo Ademar e a Lei de Segurança”, "O povo repudia Ademar" e "Viva Prestes"; por outro lado, o delegado de Americana, defensor dos interesses da elite industrial, estava certo de que, com a ajuda da polícia especializada, a cidade iria "continuar a passos largos para o progresso sem temer" os elementos comunistas.

27 No dia seguinte, exemplares de A Classe Operária chegavam aos Correios endereçados a Sturari.

28 Notícias de Hoje, São Paulo, 17 fev. 1949.

29 Relatório DOPS/SP, 21 nov. 1949. Em outro relatório, de 15 maio 1951, consta o número de 200 fábricas, sendo a grande maioria do ramo têxtil do tipo fação (tecelagens de pequeno porte). 


\section{Manifesto ao Povo de Americana e a Tribuna do Povo: o jornal do proletariado americanense}

Mesmo com a repressão policial, a célula comunista não cessava suas ações, concentrando seus esforços em Carioba. No dia 26 de fevereiro de 1950, foi distribuído o manuscrito intitulado Manifesto ao Povo de Americana, assinado pelo Comitê Municipal do Partido Comunista, tendo como foco central a luta organizada dos trabalhadores contra o imposto e o divisionismo sindical:

O Comitê Municipal do P.C.B. vem a público conclamar o povo a se organizar e lutar contra [...] o tirano Ademar de Barros e Dutra, governo este que fez correr por muitas vezes o sangue de comunistas [...] mandam assassinar operários e camponeses partidários da paz e patriotas [...] não vacilam em aumentar cada vez mais os lucros dos latifundiários e grandes industriais à custa do esfomeamento dos trabalhadores.

No imposto sindical foram gastos 5.156 .227 milhões de cruzeiros no divisionismo da classe operária, imposto ilegal e inconstitucional [...]

Conclamamos os trabalhadores a apoiar moral e financeiramente a Conferência Sindical de Montevidéu, que se realiza em março sob patrocínio da C.T.H.L. e da Federação Sindical Mundial, com representante na ONU.

Conclamamos os trabalhadores a lutar organizadamente contra o imposto sindical, é por meio deste imposto que os pelegos se mantêm no sindicato, infestando e traindo miseravelmente a classe.

$[\ldots]$

Por eleições livres no sindicato

Contra o imposto sindical

Contra o imperialismo e a guerra

$[\ldots]$

Comitê Municipal do Partido Comunista

*Leia e divulgue Tribuna do Povo, jornal do proletariado de Americana. ${ }^{30}$

As suspeitas de autoria e distribuição recaíram, nas palavras das autoridades, "inevitavelmente sobre o indivíduo Romeu Sturari", mesmo com a "falta de elementos probatórios". Não obstante, os agentes especulavam que o tipo de letra e os dizeres empregados no manifesto "coincidem perfeitamente" com as pichações encontradas nos muros. Apesar da diretriz do PCB aconselhar o abandono dos sindicatos, alguns militantes, como é o caso de Sturari, exerceram militância dupla, ou seja, contrariavam as ordens do partido, optavam por realizar campanhas para expulsar as juntas interventoras dos sindicatos, não abrindo mão dessas

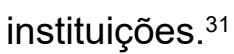

30 Manifesto ao Povo de Americana, 26 fev. 1950. Pasta Americana. Arquivo Público do Estado de São Paulo, Fundos DEOPS/SP.

31 NEGRO; SILVA, op. cit. p, 60. 
A respeito da primeira iniciativa de um jornal operário de Americana, Tribuna do Povo, ${ }^{32}$ foi possível localizar apenas o primeiro número, distribuído por Romeu Sturari no dia 7 de setembro de 1949, em Carioba, juntamente com exemplares de $A$ Luta. ${ }^{33}$ O material, uma folha tipografada frente e verso, chegou às mãos dos proprietários, os quais formalizaram a denúncia.

A data escolhida para estreia do jornal não ocorreu ao acaso, seus idealizadores interpretavam o dia 7 de setembro como um marco de liberdade. O compromisso do jornal era estar "sempre alerta, guiando e orientando todo o proletariado no caminho da revolução", que só poderia ser realizada "sob a direção do proletariado, dirigido pelo seu partido de vanguarda - o Partido Comunista". Dentre as pautas estavam: 40\% de aumento de salários, "assistência e direitos aos homens [...] igualdade em tudo para as mulheres", além de questões do Matadouro Municipal e do Sindicato de Fiação e Tecelagem de Americana.

Sobre o matadouro, o jornal denunciava o aumento no valor do abate, que de 12 cruzeiros passou para 25 por cabeça, acarretando a carestia da carne, enquanto os trabalhadores continuariam a receber o mesmo "salário de fome" para um turno das $3 \mathrm{~h}$ às $17 \mathrm{~h}$. Incentivavam que uma comissão de reivindicação fosse instaurada pelos empregados para solicitarem $50 \%$ de aumento, devendo "paralisar os serviços", pois a situação era "insalubre", dada a "imundície" do local de trabalho.

Por fim, voltavam-se contra os "pelegos" que atuavam no sindicato têxtil, exigiam a saída dos interventores, que eram "traidores a serviço dos patrões", fazendo do sindicato um antro de "divisionismo, de traição da classe operária". Como meio de encorajar os trabalhadores na luta, asseguravam que "essa junta de policiais tem medo de operários dispostos a lutar por seus direitos". Reforçando que a ação dos operários deveria ser "ou os $40 \%$ ou greve, garantida pela Constituição Federal, art. 158". Era o modo de evitar o intermédio das instituições governamentais, uma vez que a Justiça do Trabalho "só dá causa ganha para os operários em último caso".

Para as autoridades, apesar de o "ex-PCB estar articulado naquela cidade" e exercer forte propaganda, não havia ameaças de greve; mesmo assim, deter o responsável pelo manifesto e pelo jornal era uma questão de ordem. Poucos dias após a distribuição do manifesto, agentes do DOPS dirigem-se para Americana para deter Sturari que, mais uma vez, foi capaz de fugir quando desembarcava na estação ferroviária trazendo jornais de Campinas. As autoridades acreditavam ser necessária a prisão de Romeu Sturari para "desarticular provisoriamente a rede vermelha naquela cidade". Outrossim, falava-se em uma detenção que equivaleria a um "descanso de 10 dias", pois acreditavam que seria tempo suficiente para diminuir seu fervor. Nos anos seguintes, o tecelão exercia sua militância muito ligada

32 Tribuna do Povo: o jornal do proletariado americanense, 7 set. 1949. Dossiê Comunismo - PCB. Arquivo Público do Estado de São Paulo, Fundos DEOPS/SP.

33 A Luta: órgão de luta dos trabalhadores de Campinas, ago. 1949. 
à imprensa, assinando manifestos e artigos comemorativos em grandes jornais comunistas como o Hoje ${ }^{34}$ e Imprensa Popular. ${ }^{35}$

A essa altura, Romeu Sturari era reconhecido pelas autoridades como o "elemento de ligação entre parte do operariado e dos sindicatos", sendo detentor de um discurso eloquente, capaz de "citar leis e decretos", além disso, era comum "fazer barulho quando detido, mas nunca resiste à prisão", pois era liberado devido à falta de provas e artifícios legais capazes de imputar um maior período de detenção.

\section{Lei de Segurança Nacional: tempos de clandestinidade (1954-1957)}

O IMPASSE enfrentado pelas autoridades da ausência de dispositivos legais capazes de impor prisões definitivas contra Romeu Sturari foi sanado com a Lei de Segurança Nacional n ${ }^{\circ} 1.802 / 1953$, chamada Lei de Crimes Contra o Estado e a Ordem Política e Social. Em meados de março de 1954, a delegacia de Americana instaurou inquérito contra o comunista, imputando-o o artigo $9^{\circ}$ e o parágrafo $3^{\circ}$ do artigo $11^{\circ}$ da referida lei. Desse modo, seus crimes eram: tentar reorganizar o partido político dissolvido por força legal e fazer publicamente propagandas que fomentavam, por meio de boletins e panfletos, o ódio de classes, visando à subversão da ordem política e social.

Seu mandado de prisão foi expresso pelo juiz, que o sentenciou a dois anos de reclusão. Todavia, Romeu Sturari foi capaz de permanecer foragido por anos, mas, mesmo escondendose, contava com amparo judicial, conforme registros do pedido de habeas corpus negado pelo Supremo Tribunal Federal, em setembro de $1954 .{ }^{36}$ O jornal Notícias da Noite, ao noticiar a petição, qualificou o tecelão que lutava pelos direitos de sua classe como "comunista e vadio", que vinha "tentando reorganizar o partido vermelho" em Americana. ${ }^{37}$

Concomitantemente, em Americana, havia uma campanha pela concessão de anistia aos presos e condenados por crimes políticos, "abrangendo o líder comunista Romeu Sturari”. Muros amanheciam pichados com dizeres: "Anistia aos presos políticos", "Anistia a Luís Carlos Prestes", "Anistia a Romeu" e "Grande comício na cidade de Americana no dia 24/03". A divulgação do comício de anistia ficava a cargo da emissora de rádio e do jornal O Liberal. Com a necessidade de sufocar o movimento, os policiais de Americana colocaram-se em alerta, prendendo, no dia 22 de março, dois indivíduos enquanto inscreviam nos muros. Ambos alegaram ser pintores de ofício, que nada entendiam de comunismo, estavam apenas realizando serviços para Álvaro Cecchino, que pagava 50 cruzeiros para cada pintor por noite de serviço. Desse modo, mediante a repressão policial que ameaçava agir contra os trabalhadores "com todo rigor legal", o comício não ocorreu e a campanha de anistia se esmoreceu.

34 Hoje, São Paulo, 24 jan. 1952. (Romeu Sturari assina manifesto de solidariedade a jornalistas presos).

35 Imprensa Popular, 8 nov. 1953. (Romeu Sturari assina artigo de comemoração ao $36^{\circ}$ aniversário da Revolução de Outubro de 1917).

36 Diário de Notícias, Rio de Janeiro, 30 set. 1954

37 Notícias da Noite, Rio de Janeiro, 6 out. 1954. 
A cidade de Americana, em 1957, era qualificada como uma cidade "muito movimentada, embora não muito grande [...] cidade industrial muito expressiva, pois conta com mais ou menos 470 indústrias de rayon [...] o maior centro produtor de rayon da América do Sul". Não havia "favelas, mocambos e construções de madeira", sendo este ambiente impróprio para "ideias esquerdistas [...] na mente dos operários".

No âmbito político, os partidos estavam "organizados e em plena calma", não havia presença de comunistas em outros partidos, tampouco ocupando cargos na Câmara Municipal, nas escolas ou no funcionalismo público. No aspecto religioso, Americana era descrita como "verdadeiro reduto de católicos", o que corroborava para a "obediência às leis [...] dado o espírito ordeiro e cristão das massas". Complementando a projeção social, no aspecto rural, os três principais produtos eram: cana-de-açúcar, cereais e algodão. As pequenas propriedades eram predominantes, não havendo "propagandas extremistas entre as classes rurais" ou núcleo da União dos Lavradores e Trabalhadores Agrícolas do Brasil.

Mesmo foragido, o nome de Romeu Sturari não foi extinto dos relatórios do DOPS. Com a distribuição de pouco mais de 20 boletins aos operários de Carioba, às 5 h do dia 23 de abril de 1957, a polícia prendeu José Martins Moreira, empregado daquela indústria, mas que, de qualquer modo, estava atuando como "elemento de ligação do foragido". Todavia, de modo geral, a ausência de Romeu Sturari mostra-se coincidente ao momento de retração da organização dos trabalhadores.

Segundo as autoridades, no início de 1957, os comunistas não apresentavam "qualquer atividade aparente, e de certa forma, bastante desorganizados e desmoralizados perante a opinião pública". Jornais "do PCB" deixaram de ser distribuídos, "os elementos reconhecidos como perturbadores da ordem social não encontram o menor apoio no seio das classes operárias". Mesmo enfrentando forte recessão econômica e demissões em massa por meses consecutivos, com estimativas de 800 despedidos em abril, os 4,5 mil têxteis ${ }^{38}$ de Americana não organizaram qualquer ação reivindicativa.

\section{O retorno de Romeu Sturari (1958-1963)}

Após JULGADO um novo pedido de habeas corpus pelo STF, ainda no ano de 1957, Romeu Sturari teve sua sentença anulada. ${ }^{39}$ Mas, somente um ano depois, o jornal Notícias de Hoje ${ }^{40}$ estampou uma fotografia de Romeu Sturari, advertindo que o Juiz da Comarca havia revogado sua prisão. Desse modo, estava o tecelão livre de seus crimes da Lei de Segurança Nacional, podendo reaparecer na cena pública junto ao movimento dos trabalhadores. Em poucos meses Sturari foi eleito presidente do Sindicato dos Trabalhadores na Indústria de Fiação e Tecelagem de Americana. Nas eleições municipais do ano de 1959, pretendeu disputar o

38 Relatório DOPS/SP, 10 maio 1957.

39 Jornal do Commercio, Rio de Janeiro, 18 jul. 1957

40 Notícias de Hoje, São Paulo, 3 jun. 1958. 
cargo de vereador, candidatando-se pelo Partido Republicano Trabalhista (PRT), mas teve sua candidatura impugnada pelo Tribunal Regional Eleitoral devido seu histórico de crimes contra a ordem política e social. Na perspectiva do DOPS, o sindicato então presidido por Sturari, "na ocasião das eleições, exercia influência no seio de seus associados".

No segundo mês de 1959 eclodiu um movimento grevista do setor têxtil, reivindicando o cumprimento da nova lei salarial que estabeleceu o salário-mínimo de 5.100 cruzeiros. A culpa do não atendimento às normas previstas pela legislação recai sobre as facções, embora a greve tenha abarcado todas as tecelagens do município como solidariedade. Com o cumprimento da reinvindicação e o fim da greve, os agentes do DOPS constataram, depois de alguns meses, que as "pequenas indústrias de tecelagem continuam lutando com sérias dificuldades [...] em sua grande maioria, terão que encerrar suas atividades".

Mas não só as pequenas tecelagens estavam sendo afetadas, a situação geral dos têxteis era precária. A reputação do Grupo J. J. Abdalla não era nada positiva, sendo a lei reconhecida como "letra morta na fábrica do deputado J. J. Abdalla na cidade de Americana". ${ }^{41}$ As causas dos conflitos entre os trabalhadores e o empregador gravitavam em torno de salários atrasados, violação dos contratos de trabalho e aumento do uso de teares, sendo os tecelões obrigados a movimentar quatro teares, o dobro do previsto. ${ }^{42}$

O jornal Última Hora noticiou, em fevereiro de 1961, que os tecelões de Americana estavam desamparados pela lei; era a segunda vez que Sturari, enquanto presidente do sindicato, recorria à Delegacia Regional do Trabalho solicitando fiscalização do cumprimento da legislação trabalhista, "violentada e burlada quase que pela maioria das 300 empresas do ramo". O sindicalista acreditava que, ao menos, $40 \%$ dos 8 mil trabalhadores têxteis do município não eram registrados, além disso, somente 10 empresas estavam pagando o aumento de $37 \%$ acertado no último acordo. O pagamento de férias estava sendo igualmente negligenciado, bem como o adicional noturno ou insalubridade. Ademais, os salários dos trabalhadores menores de idade não eram respeitados, apesar de fazerem "serviço idêntico" ao dos adultos, e além disso, era recorrente "mulheres e menores trabalharem até altas horas da madrugada". ${ }^{43}$

Segundo Sturari, essa situação gerava problemas, desde dificuldade para "sindicalização dos operários" até a "ausência total de assistência médico-hospitalar e social". As empresas deixavam, ainda, de fazer os descontos em folhas de associados, alegando "não constarem seus nomes entre os empregados", já que não possuíam registro. Por fim, o tecelão reclamava o não pagamento de 100 mil cruzeiros pelos Abdalla ao sindicato, que "recolheu aquela importância" de seus empregados, mas não efetuou o repasse.

41 O Trabalhador Têxtil, set. 1957.

42 CORREA, Larissa Rosa. Trabalhadores têxteis e metalúrgicos a caminho da Justiça do Trabalho: leis e direitos na cidade de São Paulo - 1953 a 1964. 2007. Dissertação (Mestrado em História) - Programa de Pós-Graduação em História, Universidade Estadual de Campinas, Campinas, 2007, p. 175.

43 Última Hora, Paraná, 28 fev. 1961. 
Posteriormente, Sturari escreveu em nome do sindicato para O Liberal, ${ }^{44}$ em outubro de 1961, alertando aos trabalhadores para que se preparassem para a greve. Após reunir-se, em São Paulo, com outros líderes sindicais, realizou carreatas durante o início de dezembro convocando os trabalhadores para discutir a organização do movimento grevista caso o abono de Natal não fosse quitado. Nesse período, a pauta do $13^{\circ}$ salário era uma das principais lutas do PCB. ${ }^{45}$ Porém, os patrões e as autoridades municipais rapidamente estabeleceram acordo, evitando a eclosão da greve. Assim, ficou acertado que os trabalhadores poderiam gozar de um abono de 120 horas a ser pago ainda naquele ano.

Durante o segundo trimestre de 1963, Romeu Sturari atuou em favor da greve da Companhia Paulista de Estada de Ferro, fomentando, também, uma greve de solidariedade em Carioba para que os trabalhadores aderissem à Greve dos 700 mil, contudo, não obteve sucesso. No mesmo período, a convite de Álvaro Cecchino, "amigo pessoal de Luís Carlos Prestes", o ícone comunista visitou Americana para realização de um comício, evento que evidencia a relevância e a amplitude das relações do movimento comunista organizado na cidade.

\section{Imagem III: (da esquerda para direita) Romeu Sturari, Álvaro Cecchino e Luís Carlos Prestes em Americana (1963)}

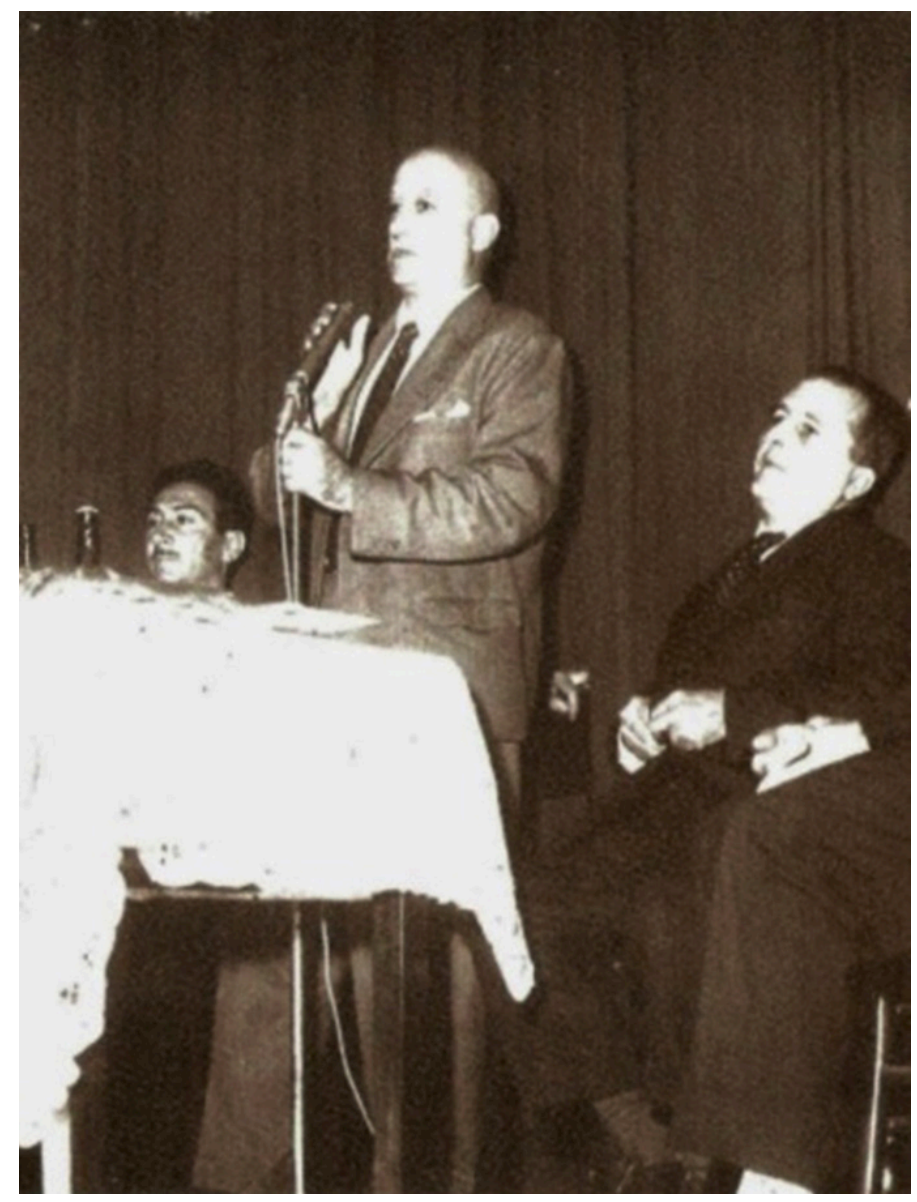

Fonte: Acervo particular da família Sturari.

44 Relatório DOPS/SP, 27 out. 1961.

45 NEGRO; SILVA, op. cit., p. 79. 


\section{O golpe militar em Americana (1964)}

COM O ADVENTO do golpe militar, a política e o movimento operário de Americana sofreram drásticas consequências. Ainda em janeiro de 1964, foi declarada greve em Carioba que perdurou 28 dias, sendo utilizada como uma das justificativas para o impeachment do prefeito Jairo de Azevedo, eleito pelo Partido Trabalhista Brasileiro (PTB). Diante da agitação política e social gerada pela tomada do poder pelos militares, as autoridades de Americana encaminharam ao DOPS informações sobre 14 pessoas "ligadas ao fato" do combate ao comunismo. O grupo era formado, sobretudo, por políticos e trabalhadores.

Sobre o ex-prefeito Azevedo, impichado pela Câmara Municipal em junho de 1964, constavam as acusações de "colaboração com Romeu Sturari", cedendo "caminhões e prestígio ao Sindicato", participando de reuniões sindicais afirmando "todo apoio ao sindicato, atacando os patrões, especialmente os Abdalla, dizendo que deviam vários milhões à Prefeitura". Em fevereiro, participou da inauguração do Sindicato Rural de Americana, filiado à Superintendência da Política Agrária (SUPRA). No dia seguinte ao golpe, reuniu-se com líderes sindicais para organizar uma passeata contra o assalto ao poder democrático.

A campanha de Azevedo contou com apoio de Sturari, que com "seu trabalho junto às massas", estava encarregado de angariar "base popular" ao candidato. Os slogans usados em comícios eram o do "Pobre Contra o Rico" e do "Tostão Contra o Milhão", proferindo discursos de "hostilidade entre o operário e o patrão". O prefeito discursava, também, em favor de alguns projetos da agenda do PCB, como direito de voto aos analfabetos e reforma agrária. Ao passo que o corporativismo sindical era usado como mecanismo para controlar o operariado, a aliança PTB-PCB, expressa em Azevedo-Sturari, servia-se dos sindicatos para organizar os trabalhadores em favor do direito à greve. ${ }^{46}$

$\mathrm{Na}$ visão das autoridades, com a vitória do PTB os comunistas "sentiram-se fortes", organizando a greve de Carioba por contarem com apoio do prefeito e outros cinco vereadores do PTB. Por outro lado, ao analisarmos os processos do Tribunal Regional do Trabalho sobre essa paralisação, vislumbramos motivações geradas por problemas trabalhistas e não puramente políticos.

Quando, no dia 6 de janeiro, declararam greve, os trabalhadores não tinham recebido os salários dos meses de novembro e dezembro, juntamente com o abono de Natal de 1963. Após tentativas frustradas de negociação entre o sindicato e o empregador, a Federação dos Trabalhadores Têxteis de Fiação e Tecelagem decidiu, no dia 20 de janeiro, instaurar processo na Justiça do Trabalho. ${ }^{47}$ No entendimento dos próprios trabalhadores, os Abdalla protelavam os pagamentos como meio de incentivar a rescisão de contrato para que os empregados abdicassem de seus direitos e de sua morada. Os grevistas exigiam, ainda,

46 NEGRO; SILVA, op. cit., p. 85.

47 Processo TRT/SP 23/64-A. 
a não demissão dos grevistas, o pagamento dos dias de paralisação e o recebimento dos salários na fábrica. Uma vez que, conforme Larissa Corrêa, era prática habitual dos Abdalla orientar os trabalhadores para que fossem receber no banco, ocasionando longas filas de espera. Não raro, as agências encerravam suas operações e muitos operários tinham de retornar no dia seguinte para resgatar seus rendimentos. ${ }^{48}$

Retomando os indivíduos listados pelo delegado, constava o vereador Willi Cordenonsi (PTB), encarregado de um dos institutos de previdência que, durante reunião na Câmara, proferiu verbalmente o pedido da legalização do PCB. Em contrapartida, o Círculo Operário de Americana organizou um grupo de trabalhadores para irem até a Câmara entregar um abaixo-assinado com 4 mil assinaturas de "católicos que protestavam" 49 contra a fala do vereador.

Do âmbito rural, consta somente o nome de Francisco Prado, "presidente do recém-instaurado Sindicato Rural de Americana, semianalfabeto, influenciado, porém, por Sturari”. A instituição em questão é a primeira iniciativa sindical dos trabalhadores rurais da cidade. As reuniões de articulação e criação do sindicato ocorreram, segundo Prado, sob incentivo e mediação de Sturari, o qual tinha contato com representantes da SUPRA. No segmento metalúrgico, Dario Pompeu e Osório Voletti eram apontados como principais agitadores das Indústrias Nardini, ${ }^{50}$ sendo representantes do Sindicato dos Metalúrgicos de Campinas e dirigentes da Delegacia dos Metalúrgicos de Americana.

Entre os servidores públicos, o diretor do Grupo Escolar do Jardim São Paulo Hipólito Gonçalves era acusado de atividades comunistas. Gonçalves atuou como propagandista da campanha de Azevedo, além de prestar serviço voluntário ao sindicato e participar de assembleias. Em sua posse foram encontrados mimeógrafo e máquina de escrever patrimoniados do sindicato, material cedido por Sturari. Tendo tomado parte na greve de Carioba, era o principal suspeito de ter redigido os boletins circulados durante o movimento.

Dentre os trabalhadores têxteis, a atenção recaía sobre os dirigentes do sindicato: Romeu Sturari, presidente; Nelson Zanetti, tesoureiro; e, por fim, Dirceu Leão, secretário, que ocupava, também, o cargo de vereador suplente pelo PTB. Como garantia da ordem, a polícia de Americana invadiu, menos de uma semana após o golpe, a sede do sindicato à rua Vieira Bueno, $n^{\circ} 48$. A essa altura, Sturari já se encontrava foragido, mas devido ao material encontrado na instituição, foi indiciado na Lei de Segurança Nacional no 1.802/53, artigo $11^{\circ}$, alínea "a", parágrafos $1^{\circ}$ e $3^{\circ}$. Seu crime consistia em fazer propaganda e distribuição de material textual para subversão da ordem política e social, havendo agravante por distribuir em fábricas. Para as autoridades, estava claro que o sindicato atuava como "verdadeira célula comunista", sendo medida cabível a prisão de seus dirigentes.

Quando interrogados sobre suas relações com Romeu Sturari, todos os investigados negaram ter ligação de caráter político com ele ou partilhar do ideário comunista. Os membros

48 CORRÊA, op. cit., p. 167-168.

49 O Liberal, Americana, 19 mar. 1964.

50 As Indústrias Nardini somavam 300 trabalhadores em junho de 1957, conforme relatório do DOPS/SP. 
da diretoria do sindicato diziam reprovar a conduta extremista do presidente, advertindo-o que essa "não era a finalidade do sindicato". Outros alegavam partilhar dos "princípios católicos e democráticos", afirmando ter participado da Marcha da Família com Deus pela Liberdade e da Campanha Ouro para o Bem do Brasil. O vereador Willi Cordenonsi (PTB), além de apresentar os argumentos citados acima, alegou ter votado favorável tanto ao impeachment de Jairo Azevedo (PTB) quanto à moção de louvor da Câmara Municipal aos militares, mantendo-se "firme ao lado dos verdadeiros democratas". Por fim, afirmou ter se desligado do PTB, assim como os demais vereadores do partido.

Álvaro Cecchino não foi poupado. As autoridades exigiam sua prisão preventiva devido à "célula comunista que criou dentro de sua indústria", colaborando para a formação de "vários líderes esquerdistas". Diferentemente de todos os outros depoentes, Cecchino disse abertamente partilhar da teoria marxista, sendo favorável à política de João Goulart. Questionado sobre Sturari, disse que apesar da relação de amizade, o tecelão passou a hostilizá-lo e chamá-lo de reacionário após assumir a presidência do sindicato. Como álibi para evidenciar que não era mais um comunista em atividade, Cecchino afirmou ter instaurado ações na Justiça do Trabalho contra alguns de seus empregados que vinham participando dos movimentos grevistas organizados por Sturari. Prestadas as declarações e por "estar já velho, doente, e não mais em atividade", foi liberado.

Após quase um ano foragido, Romeu Sturari foi detido, informando não mais residir em Vila Carioba, mas em Vila Manoel, no mesmo município. Não havia espaço para sua conduta comunista em Carioba. Em seu ponto de vista, toda a perseguição e prisões foram "ocasionadas por atritos entre seu ex-patrão J. J. Abdalla", que o denunciava "visando a expulsá-lo da casa onde residia”. A prática de denunciar e promover a espionagem dos próprios empregados era recorrente, já que os industriais vislumbravam na polícia um costumeiro aliado na conservação de seus domínios privados sobre os mundos do trabalho. ${ }^{51}$

Perguntado sobre Cecchino, Sturari afirmou ser um companheiro que durante muitos anos atuou em conjunto, tendo também trabalhado na tecelagem do industriário durante o ano de 1953, mas suas relações foram abaladas, em 1962, após ser nomeado juiz vogal e atuar "em defesa dos empregados de Álvaro" na Justiça do Trabalho. Admitiu, ainda, ser comunista e ter participado, bem como organizado, diversos movimentos grevistas, os quais eram determinados sem, necessariamente, perpassar pelo sindicato. As reuniões e decisões eram tomadas em "assembleias organizadas por ele mesmo". Em contrapartida, reafirmou seu caráter "de família católica", salientando as boas relações que tinha com monsenhor Maggi, pois que "as festas do sindicato eram sempre feitas em salões de propriedade da Igreja". Dadas as declarações, foi recolhido à prisão, momento em que é encerrada a trajetória de Romeu Sturari nos arquivos do DOPS.

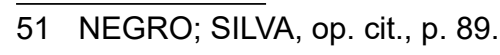


Por meio dos registros de sua carteira profissional, é possível dizer que o tecelão trabalhou, em meados de 1958, na Têxtil Carauma, ascendendo ao cargo de sócio dessa indústria no final de 1959, permanecendo nesse posto até sua prisão ser decretada em 1964. Após ser colocado em liberdade, Sturari não exerceria mais, pelo menos formalmente, a função de tecelão. O único registro posterior à prisão data de maio de 1967 , na função de servente na construção civil na cidade de Campinas, contrato que seria encerrado três meses depois. Pode-se supor, assim, que tanto no ramo têxtil quanto na cidade de Americana, eram escassas as possibilidades de emprego para Romeu Sturari que, apesar de fiel servidor da causa operária, passou a ser evitado socialmente, inclusive, por seus vizinhos.

Faleceu no dia 14 de dezembro de 1978, aos 60 anos de idade, sendo sepultado no Cemitério da Saudade, em Americana. Entretanto, três anos antes de sua morte, continuava a ser citado pelas autoridades, dessa vez, na documentação do Serviço Nacional de Informação (SNI), como "militante do PCB". 52

\section{Imagem IV: Romeu Sturari (1973)}

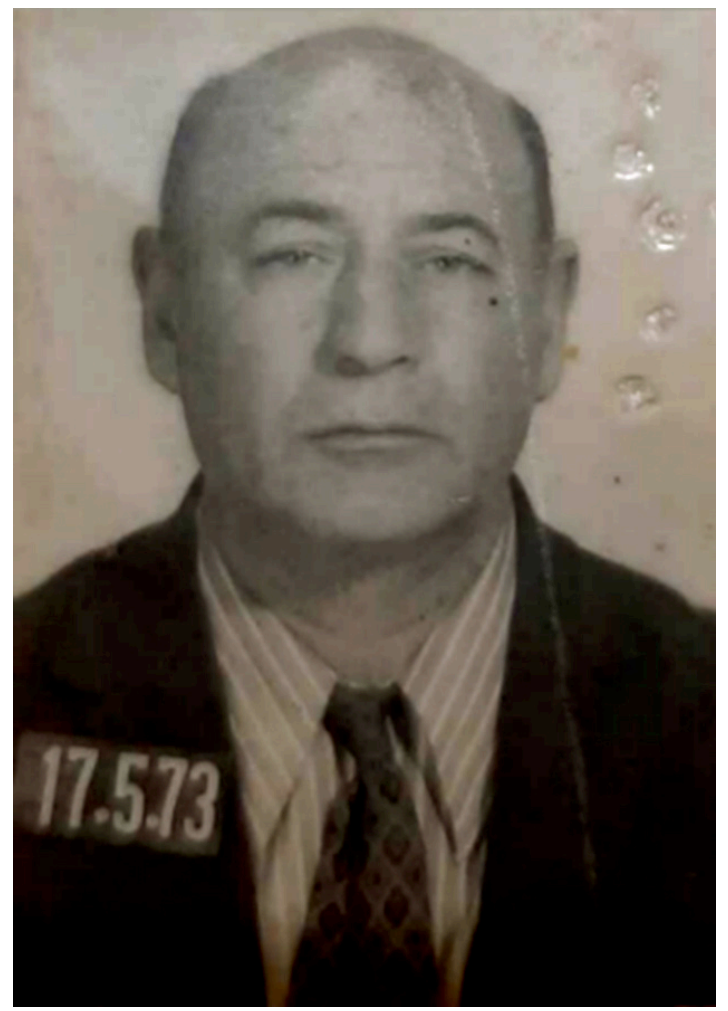

Fonte: Acervo particular da família Sturari.

\section{A Grande Greve de Carioba (1966-1967)}

No SEGUNDO SEMESTRE de 1965, Carioba apresentava sinais de graves problemas financeiros. A situação preocupava os parlamentares, sobretudo o deputado federal Herbert Levy que

52 Arquivo Nacional, Fundo: Serviço Nacional de Informações (SNI). 
apresentou, na Câmara Federal, seu telegrama enviado ao ministro do Trabalho sobre a tecelagem.

Seu discurso, noticiado pelos jornais Folha de São Paulo ${ }^{53}$ e O Liberal, ${ }^{54}$ afirmava ser "verdadeiramente dramática" a situação, pois os proprietários agiam de forma "desumana e antissocial", que, além do atraso salarial "há meses", realizavam demissões "sem pagamento de indenização". Na última dispensa, somavam-se 200 trabalhadores sem ressarcimento. Diante desse contexto, Levy solicitava a "intervenção direta do governo", uma vez que a "ação morosa da Justiça" não era suficiente para garantir os direitos dos trabalhadores.

Contudo, conforme as forças policiais, apesar da situação de penúria, não era cogitada "paralisação do trabalho por greve", não havendo "nenhum elemento incitador de subversão". Mas quanto aos salários, além de estarem em atraso, os empregadores ofereciam a opção de pagamento através de produtos produzidos pelo Grupo J. J. Abdalla, como "cimento, materiais de construção, mantimentos" e até mesmo tecido. Em uma situação calamitosa, os trabalhadores tinham de vender a própria produção para garantirem sua subsistência.

Com o "expurgo" de "agitadores profissionais e políticos inescrupulosos [...] extirpados do meio trabalhador [...] Romeu Sturari e Jairo Azevedo [...] a insatisfação não contou com o fermento prodígio para transformar-se em agitação". Outro fator que contribuiu para a manutenção da ordem era o atendimento das necessidades básicas do operariado: casa, água e luz. Itens, como já dito, fornecidos sem custos pelo patrão.

Entretanto, com a persistência da situação por um ano, os trabalhadores decidiram, no início de 1966, apelar para a Justiça do Trabalho, tendo em vista que em março daquele ano muitos trabalhadores ainda não tinham recebido o salário de dezembro. Diante dessa situação, inevitavelmente o empregador era condenado pela JT e propunha um acordo, o qual era aceito e acarretava o encerramento do processo. Nas palavras do delegado, "tudo voltava à estaca zero", pois mesmo quando os acordos eram cumpridos, os atrasos voltavam a ocorrer, acarretando a sobrecarga da JT.

O representante dos empregadores era Nicolau Abdalla, vereador eleito que "gozava de grande simpatia entre os trabalhadores por seu trato humano e bondade de coração". Por residir em Carioba, era "acessível, amigo dos trabalhadores e 'compadre' de muitos deles". Mas seu status de benquisto sofria constante depreciação entre os empregados, dadas as dificuldades de gestão. Para quantificarmos em dados aproximados, em 1964, a empresa possuía 1.100 funcionários, enquanto no início de 1966 contava com somente 650 .

Era comum a aglomeração de grupos de trabalhadores nos escritórios da fábrica na expectativa de receber. Em março houve "ameaças de depredação e até de esforço físico". A situação preocupava as autoridades do DOPS, assim, um agente da instituição solicitou e acompanhou Nicolau Abdalla e o presidente do sindicato até São Paulo para que fosse

53 Folha de São Paulo, São Paulo, 19 ago. 1965.

54 O Liberal, Americana, 24 ago. 1965. 
firmado um acordo. Ficou acertado que a empresa pagaria parcelas proporcionais ao número de operários que cada família possuísse. Para realização do acerto, cinco agentes do DOPS estavam em Carioba desde as primeiras horas do dia, igualmente outros 12 soldados da delegacia de Americana estavam de "sobreaviso para qualquer emergência". Apesar de preparadas, as autoridades não tiveram de agir.

Insatisfeitos, os trabalhadores reuniram-se, em meados de julho de 1966, em Assembleia Geral Extraordinária, organizada pelo Sindicato dos Trabalhadores na Indústria de Fiação e Tecelagem, em conjunto com o Sindicato de Mestres e Contramestres nas Indústrias de Fiação e Tecelagem. Assim, os sindicatos que deveriam atuar como mecanismo de controle estatal sobre os operários possibilitaram, mais uma vez, romper com a dívida de lealdade para com o patrão, protagonizando o conflito de classe..$^{55}$

Conforme ata da reunião, dos 681 trabalhadores empregados em Carioba, 542 compareceram à reunião para discutirem:

1) complementação do pagamento relativo ao $13^{\circ}$ salário (Abono de Natal correspondente ao ano de 1965); 2) pagamento das importâncias correspondentes às férias vencidas e gozadas por trabalhadores; 3 ) pagamento dos salários dos meses de abril, maio e junho de 1966 [...] deliberar sobre a decretação do movimento grevista. ${ }^{56}$

No total, 523 trabalhadores computaram seus votos, sendo seis votos em branco e apenas um não favorável à paralização. Assim, ficou decidido que "absterão pacificamente do trabalho" a partir do dia primeiro do mês de agosto, "tudo em obediência às normas legais vigentes e conforme aceitação" dos empregados. Sendo a ata lavrada e uma cópia encaminhada à Justiça do Trabalho.

Desde o primeiro dia de agosto de 1966 até o dia 15 de abril de 1967, Carioba não funcionou, os únicos serviços mantidos na fábrica foram os de portaria e vigilância noturna. A greve foi considerada legal pela Justiça do Trabalho, sendo determinado o pagamento dos dias de paralisação, o $13^{\circ}$ de 1966 e os meses de salários atrasados. Contudo, a decisão considerou os atrasos desde agosto, causando descontentamento entre os empregados, que argumentaram haver atrasos anteriores que motivaram a deflagração da greve no mês respectivo. Outro problema que afligia os operários era a obrigatoriedade de retorno, mesmo sem haver data para os pagamentos dos valores, que apesar de estarem garantidos judicialmente, poderiam sofrer longas protelações até serem quitados. Entretanto, não podendo descumprir a decisão, decidiram retornar às atividades e interpelar através do sindicato.

Quando as atividades foram retomadas, apenas 600 funcionários permaneciam empregados na tecelagem. Os salários em atraso estavam sendo quitados parceladamente, mas o processo sobre o pagamento dos dias de greve e valores rescisórios permaneciam

55 NEGRO; SILVA, op. cit., 88-89.

56 Pasta Americana. Arquivo Público do Estado de São Paulo, Fundos DEOPS/SP. 
em aberto. Era uma "situação de verdadeira calamidade", conforme analisava o delegado de Americana. A autoridade policial acreditava "não haver condições de trabalho após a longa paralisação, eis que a maquinaria é obsoleta. Grande parte da mesma foi vendida e outra encontra-se penhorada para o pagamento de executivos fiscais. Praticamente não há matéria-prima". Como previsto, a situação de Carioba era irremediável, mesmo sob intervenção direta do governo federal e com a prisão e confisco de bens de José João Abdalla, a Fábrica de Tecidos Carioba agonizou até o final de 1976, encerrando suas atividades. A Vila Operária de Carioba foi tema de disputas judiciais entre os moradores e os herdeiros da família Abdalla; por fim, foi desocupada e demolida em meados de 1980. ${ }^{57}$ Parte dos trabalhadores, após longa disputa jurídica, foram indenizados com terrenos na região correspondente ao bairro Cariobinha em Americana.

\section{Conclusão}

CONCLUI-SE, assim, que Romeu Sturari foi um grande representante dos trabalhadores de Carioba, os quais envolveram-se em lutas por seus direitos, sobretudo após 1966. Mas não somente, visto que sua trajetória nos permitiu analisar ações do Comitê Municipal do Partido Comunista Brasileiro em conjunto com os trabalhadores de Americana e de Vila Carioba, evidenciando a existência de projetos políticos da classe operária que, mesmo durante a redemocratização, sofreram severas perseguições das autoridades policiais. Além disso, vislumbramos as diferentes estratégias de organização e modos de luta adotados pelos trabalhadores nas variadas conjunturas.

Não podemos deixar de levar em conta os objetivos da Delegacia de Ordem Política e Social na produção da documentação sobre Carioba. Ao supervalorizar a ação e o protagonismo de Romeu Sturari na mobilização operária, colaboravam com a cosmovisão dos agentes estatais que atribuíam a difusão do comunismo aos militantes de vanguarda, pois os trabalhadores, em sua maioria migrantes rurais do interior, eram compreendidos como politicamente ignorantes e facilmente manipuláveis. Assim, é necessário ponderar até que ponto os agentes legais desprezavam a politização das classes de base que, apesar de influenciados pelo paternalismo e pelas políticas assistencialistas existentes na tecelagem, foram capazes de se articular enquanto classe para reivindicações de direitos durante a Grande Greve de Carioba, mesmo sem a participação de Sturari.

Assim, seja pelo viés partidário ou sindical, a luta classista se fazia presente e mobilizava os trabalhadores de Vila Operária de Carioba. Outrossim, a investigação permitiu aferir parte dos efeitos do golpe militar na política e no movimento operário do município. Por fim, apesar dos agentes do DOPS estarem frequentemente presentes em Carioba durante os 20 anos

57 A análise do processo de disputa e demolição da Vila Operária de Carioba foge do escopo do presente artigo, entretanto, é reconhecida a importância da análise desse processo que carece de produções historiográficas a seu respeito. 
analisados, seus relatórios reforçavam sempre os aspectos de combate ao comunismo e agitação operária, adotando silêncio sepulcral sobre aspectos como acidentes ou condições de trabalho na tecelagem.

Recebido em 23/04/2021

Aprovado em 03/08/2021 